\title{
THE INFLUENCE OF CARBON, MANGANESE AND SILICON CONTENT UPON THE HARDNESS OF PHOSPHORUS CAST IRON USED IN MANUFACTURING ROLLING STOCK BRAKING SHOES
}

\author{
Ana Socalici, Liviu Pascu, Erika Ardelean, Teodor Heput
}

Original scientific paper

The paper introduces the correlations between the hardness at various points of the braking shoes, according to provisions and standards, and the carbon, manganese and silicon content of the phosphorous cast iron they are made of. The correlations are given both in analytical and graphical form. They allow the determination of the optimal variation domains for the independent parameters (the content of carbon, manganese and silicon).

Keywords: brake shoes; casting; hardness; iron phosphorus; rolling stock

Utjecaj sadržaja ugljika, mangana i silicija na tvrdoću fosfornog lijevanog željeza rabljenog u izradi kočionih papuča tračničkih vozila

U radu se daju korelacije između tvrdoće u različitim točkama kočionih papuča, u skladu s odredbama i normama, i sadržaja ugljika, mangana i silicija fosfornog lijevanog željeza od kojeg su izrađene. Korelacije se daju i u analitičkom i grafičkom obliku. One omogućuju određivanje optimalnih područja varijacije za nezavisne parametre (sadržaj ugljika, mangana i silicija).

Ključne riječi: fosforno željezo; kočione papuče; lijevanje; tračnička vozila; tvrdoća

\section{Introduction}

Cast iron properties are determined both by the nature of the metallic mass and by the quantity, shape and size of graphite segregation elements. The hardness and plasticity properties increase when the quantity and dimensions of the graphite segregation elements diminish and when their compactness grows [1].

An increase of the carbon and silicon content leads to a larger quantity of graphite, respectively a higher degree of cast iron graphitization. When carbon and silicon content grows, the traction strength and the hardness decrease, because the quantity of graphite and ferrite in the pig iron grows.

The growth of manganese content determines an increase of the traction strength, due to its action of pearlite formation, respectively an increase of hardness, its values being higher as the carbon saturation degree is lower.

A higher content of sulphur increases the hardness of the cast iron.

Phosphorous reduces the solubility of carbon in the cast iron, which favours the graphitization process. Phosphorous is slightly soluble in the solidified cast iron, the reason for which it is found to be almost entirely as phosphorous eutectic [2]. The amount of phosphorous eutectic directly depends on the content of phosphorous.

Phosphorous eutectic is distributed as isolated segregations, slightly elongated at one end or distributed in a continuous or discontinuous lattice at the limit of the primary structure grains.

Phosphorus influences the mechanical properties of the cast iron by the structural modifications it produces: graphite grain size reduction, the increase of the perlite ratio and the formation of the phosphorous eutectic. Phosphorous eutectic is hard $(500 \div 600 \mathrm{HB})$ and brittle, with a significant influence upon the properties of the cast iron. The hardness is directly proportional to the content of phosphorous.

The brake shoes are made of phosphorous pig iron that is cast according to specifications approved by AFER [3]. Phosphorous cast iron is the grey pearlitic one with an increased concentration of phosphorus $(0,25 \div 1,5 \%)$, which grants the formation of the ternary phosphorous eutectic - the steadite $-\mathrm{Ef}\left(\mathrm{Fe}_{3} \mathrm{C}+\mathrm{Fe}_{3} \mathrm{P}+\mathrm{Fe}-\mathrm{C}-\mathrm{P}\right)$, hard eutectic $(650 \mathrm{HB})$, brittle, having a low melting temperature $\left(953{ }^{\circ} \mathrm{C}\right)$. The structure resulting (Fig.1) from pearlite $(\mathrm{P})$, graphite $(\mathrm{G})$, ferrite $(\mathrm{F})$ and the phosphorous eutectic (Ef) determines the wear resistance of the semifinished part [4].

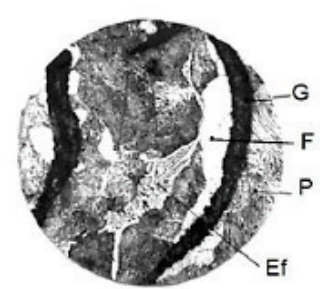

Figure 1 Cast iron phosphorous: attack nital $2 \%, 400 \times$

While braking, the superficial layer of the brake shoe can reach temperatures of $800 \div 900{ }^{\circ} \mathrm{C}$, temperatures at which some structural constituents can melt. On cooling down, structural modifications may arise, alongside with an increase of hardness [5]. By increasing the content of phosphorus in the cast iron, phosphorous eutectic is formed inside its structure.

This eutectic melts at the high temperatures resulting from braking and occupies the space created at the limit of austenite grains, which favours a better contact wheel shoe and a higher friction coefficient, which increases the efficiency of braking. 


\section{Laboratory experiments}

The paper establishes the influence of the structural chemical elements upon the physical and chemical characteristics of the material the brake shoe is made of [6 $\div 8]$. This is why the chemical structure and the physicalmechanical characteristics have been analysed for 25 charges of P10 phosphorous cast iron elaborated by a profile company.

An important characteristic with a significant influence upon the useful life of brake shoes is hardness. Hardness is tested according to SR EN ISO 6506-1:2006. Hardness is measured at the extreme points of the brake shoe (1 and 2 - Fig. 2a), on its front, after having removed $2 \mathrm{~mm}$ of material by grinding or rectifying and at three points located diagonally ( $s, m$ and $j-$ Fig. $2 \mathrm{~b}$ ), on the surface of a sample obtained by cross cutting the shoe.

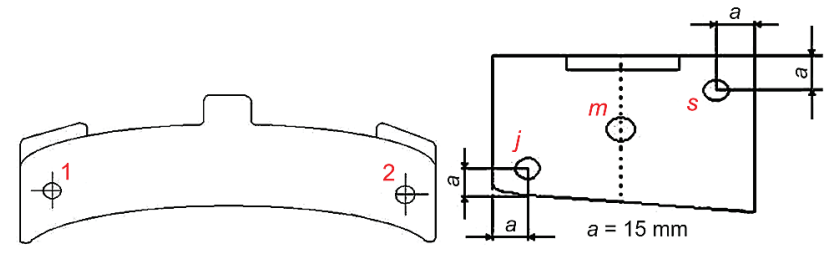

a) shoe

b) sample

Figure 2 Sampling areas hardness shoe

The brake shoe must have on its lateral surface, as well as on the cross section, a Brinell hardness ranging within $197 \div 225 \mathrm{HB}$.

Hardness has been determined, according to the standards and norms in force, for each charge analysed at five points, according to the sampling areas for shoe hardness, shown in Fig. 2.

The resulting experimental data pertaining to the influence of chemical composition on hardness have been processed in MATLAB and the results are given both in analytical and graphical form. The processed data resulted in $2^{\text {nd }}$ degree correlation equations between hardness $\left(H B_{1}, H B_{2}, H B_{s}, H B_{m}, H B_{j}\right.$ respectively the means for the shoe surface $\left(H B_{1}+H B_{2}\right) / 2$ and for its cross section $\left(H B_{s}+H B_{m}+H B_{j}\right) / 3$ - dependent parameters) and the elements present in the chemical composition $(\mathrm{C}, \mathrm{Mn}$ and $\mathrm{Si}$ - independent parameters).

The resulting correlations are given in a graphical form only for the means obtained for the surface of the brake shoe and along its cross section.

Correlation equations for hardness variation depending on the content of carbon and silicon are:

$H B_{1}=79,3 \cdot \mathrm{C}^{2}+27,6 \cdot \mathrm{Si}^{2}+3,4 \cdot \mathrm{C} \cdot \mathrm{Si}-473,9 \cdot \mathrm{C}-$ $-109,5 \cdot S i+1014,7$

Correlation coefficient: $R^{2}=0,66$. Point of minimum: $\mathrm{C}=$ $2,95 \% ; \mathrm{Si}=1,80 \%, H B_{1}=216,45 \mathrm{HB}$.

$$
\begin{aligned}
& H B_{2}=44,44 \cdot \mathrm{C}^{2}+13,96 \cdot \mathrm{Si}^{2}-29,79 \cdot \mathrm{C} \cdot \mathrm{Si}- \\
& -197,07 \cdot \mathrm{C}+50,08 \cdot \mathrm{Si}+437,75
\end{aligned}
$$

Correlation coefficient: $R^{2}=0,75$. Point of minimum: $\mathrm{C}=$ $2,51 \%$; $\mathrm{Si}=0.88 \%, H B_{2}=212,2 \mathrm{HB}$.
$H B_{s}=180,6 \cdot \mathrm{C}^{2}+27,1 \cdot \mathrm{Si}^{2}-26,4 \cdot \mathrm{C} \cdot \mathrm{Si}-$

$-1073,9 \cdot \mathrm{C}-4,8 \cdot \mathrm{Si}+1881,6$

Correlation coefficient: $R^{2}=0,62$. Point of minimum: $\mathrm{C}=$ $3,09 \%$; $\mathrm{Si}=1,59 \%, H B_{s}=218,57 \mathrm{HB}$.

$H B_{m}=-118,12 \cdot \mathrm{C}^{2}+51,29 \cdot \mathrm{Si}^{2}-13,09 \cdot \mathrm{C} \cdot \mathrm{Si}-$

$-772,72 \cdot \mathrm{C}-133,01 \cdot \mathrm{Si}-906,29$

Correlation coefficient: $R^{2}=0,56$. Inflection point: $\mathrm{C}=$ $3,17 \% ; \mathrm{Si}=1,70 \%, H B_{s}=207,84 \mathrm{HB}$.

$H B_{j}=-57,38 \cdot \mathrm{C}^{2}+7,69 \cdot \mathrm{Si}^{2}+182,53 \cdot \mathrm{C} \cdot \mathrm{Si}+$

$+59,26 \cdot \mathrm{C}-602,52 \cdot \mathrm{Si}+629,96$

Correlation coefficient: $R^{2}=0,56$. Inflection point: $\mathrm{C}=$ $3,16 \% ; \mathrm{Si}=1,66 \%, H B_{s}=222,70 \mathrm{HB}$.

$$
\begin{aligned}
& \frac{H B_{1}+H B_{2}}{2}=79,2 \cdot \mathrm{C}^{2}+94,3 \cdot \mathrm{Si}^{2}+7,4 \cdot \mathrm{C} \cdot \mathrm{Si}- \\
& -518,2 \cdot \mathrm{C}-364,8 \cdot \mathrm{Si}+1370,3
\end{aligned}
$$

Correlation coefficient: $R^{2}=0,61$. Point of minimum $\mathrm{C}=$ $3,16 \%$; $\mathrm{Si}=1,66 \%,\left(H B_{1}+H B_{2}\right) / 2=215 \mathrm{HB}$.

$\frac{H B_{s}+H B_{m}+H B_{j}}{3}=197,1 \cdot \mathrm{C}^{2}+12,8 \cdot \mathrm{Si}^{2}+$
$+106,5 \cdot \mathrm{C} \cdot \mathrm{Si}-1384,9 \cdot \mathrm{C}-391,6 \cdot \mathrm{Si}+2679,2$

Correlation coefficient: $R^{2}=0,76$. Inflection point is located outside the technology.
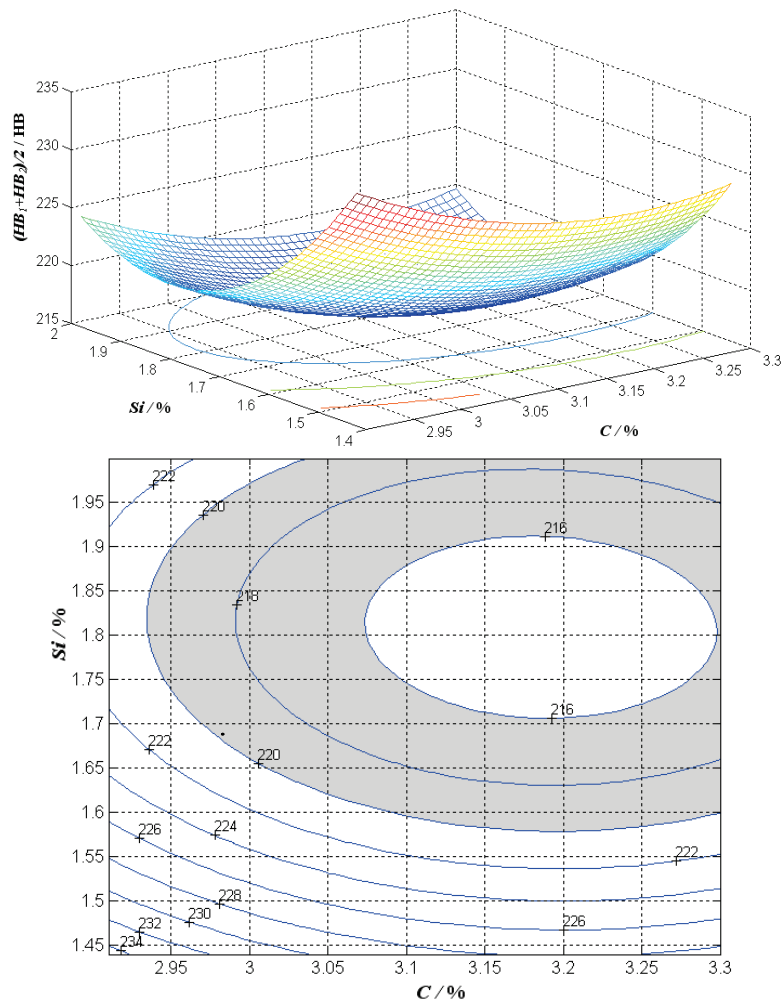

Figure $3\left(H B_{1}+H B_{2}\right) / 2=f(\mathrm{C}, \mathrm{Si})-$ correlation $2^{\text {nd }}$ degree 

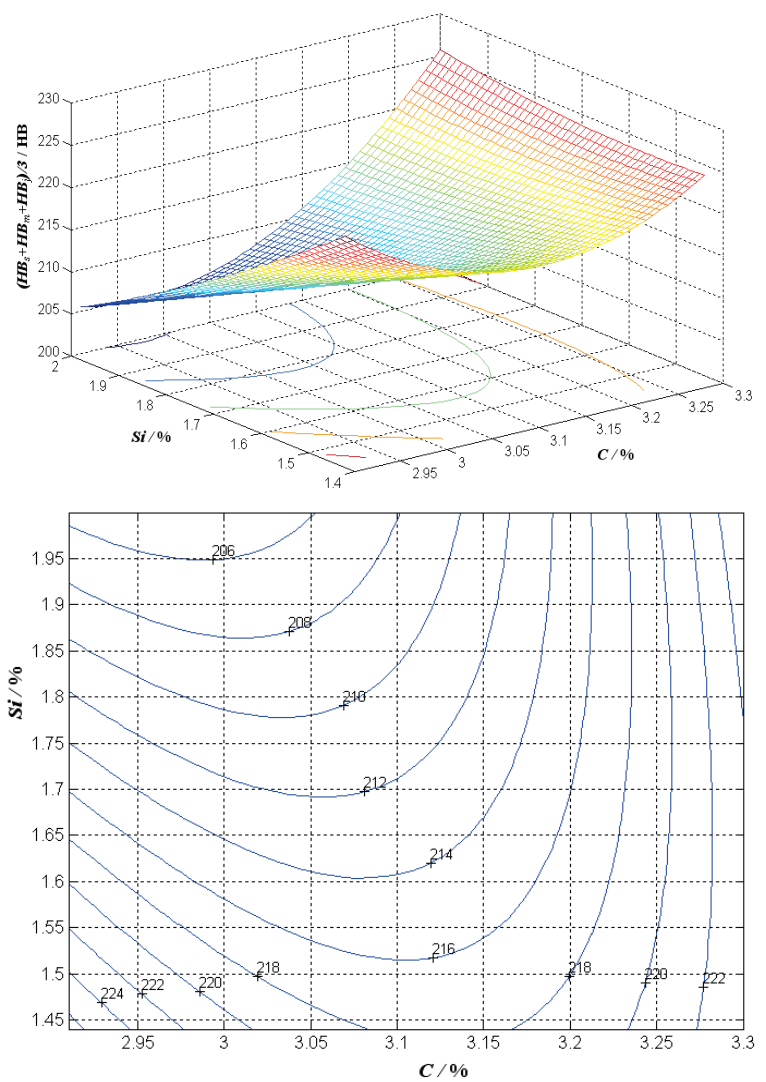

Figure $4\left(H B_{s}+H B_{m}+H B_{j}\right) / 3=f(\mathrm{C}, \mathrm{Si})-$ correlation $2^{\text {nd }}$ degree

Correlation equations for hardness variation depending on the content of carbon and manganese are:

$H B_{1}=97,73 \cdot \mathrm{C}^{2}-38,57 \cdot \mathrm{Mn}^{2}-67,84 \cdot \mathrm{C} \cdot \mathrm{Mn}-$

$-537,78 \cdot \mathrm{C}+272,09 \cdot \mathrm{Mn}+922,93$

Correlation coefficient: $R^{2}=0,66$. Inflection point: $\mathrm{C}=$ $3,04 \% ; \mathrm{Mn}=0,84 \%, H B_{1}=219,34 \mathrm{HB}$.

$\mathrm{HB}_{2}=48,9 \cdot \mathrm{C}^{2}+96,19 \cdot \mathrm{Mn}^{2}-2,76 \cdot \mathrm{C} \cdot \mathrm{Mn}-$

$271,2 \cdot \mathrm{C}-120,5 \cdot \mathrm{Mn}+635,4$

Correlation coefficient: $R^{2}=0,79$. Point of minimum: $\mathrm{C}=$ $2,79 \% ; \mathrm{Mn}=0,66 \%, H B_{2}=216,71 \mathrm{HB}$.

$H B_{s}=216,2 \cdot \mathrm{C}^{2}-6,4 \cdot \mathrm{Mn}^{2}-114,1 \cdot \mathrm{C} \cdot \mathrm{Mn}-$

$1238,5 \cdot \mathrm{C}+452,5 \cdot \mathrm{Mn}+1974$

Correlation coefficient: $R^{2}=0,67$. Inflection point: $\mathrm{C}=$ $3,13 \%$; $\mathrm{Mn}=0,81 \%, H B_{s}=219,78 \mathrm{HB}$.

$H B_{m}=-154,64 \cdot \mathrm{C}^{2}+19,82 \cdot \mathrm{Mn}^{2}+162,32 \cdot \mathrm{C} \cdot \mathrm{Mn}-$ $+859,76 \cdot \mathrm{C}-506,99 \cdot \mathrm{Mn}-978,81$

Correlation coefficient: $R^{2}=0,73$. Inflection point: $\mathrm{C}=$ $3,01 \% ; M n=0,44 \%, H B_{m}=203,67 \mathrm{HB}$.

$H B_{j}=2,94 \cdot \mathrm{C}^{2}-73,81 \cdot \mathrm{Mn}^{2}+57,7 \cdot \mathrm{C} \cdot \mathrm{Mn}-$

$-171,64 \cdot \mathrm{C}-33,82 \cdot \mathrm{Mn}+488,47$
Correlation coefficient: $R^{2}=0,66$. Inflection point: $\mathrm{C}=$ $2,88 \% ; \mathrm{Mn}=0,88 \%, H B_{j}=225,84 \mathrm{HB}$

$\frac{H B_{1}+H B_{2}}{2}=97,38 \cdot \mathrm{C}^{2}-2,94 \cdot \mathrm{Mn}^{2}-132 \cdot \mathrm{C} \cdot \mathrm{Mn}-$
$-527,86 \cdot \mathrm{C}+421,29 \cdot \mathrm{Mn}+912,39$

Correlation coefficient: $R^{2}=0,37$. Inflection point: $\mathrm{C}=$ $3,16 \% ; \mathrm{Mn}=0,66 \%,\left(H B_{1}+H B_{2}\right) / 2=218,21 \mathrm{HB}$.

$$
\begin{aligned}
& \frac{H B_{s}+H B_{m}+H B_{j}}{3}=307,8 \cdot \mathrm{C}^{2}-79,6 \cdot \mathrm{Mn}^{2}- \\
& -212,3 \cdot \mathrm{C} \cdot \mathrm{Mn}-1753,9 \cdot \mathrm{C}+792,3 \cdot \mathrm{Mn}+2637,5
\end{aligned}
$$

Correlation coefficient: $R^{2}=0,83$. Inflection point: $\mathrm{C}=$ $3,12 \% ; \mathrm{Mn}=0,80 \%,\left(H B_{s}+H B_{m}+H B_{j}\right) / 3=214,02 \mathrm{HB}$.
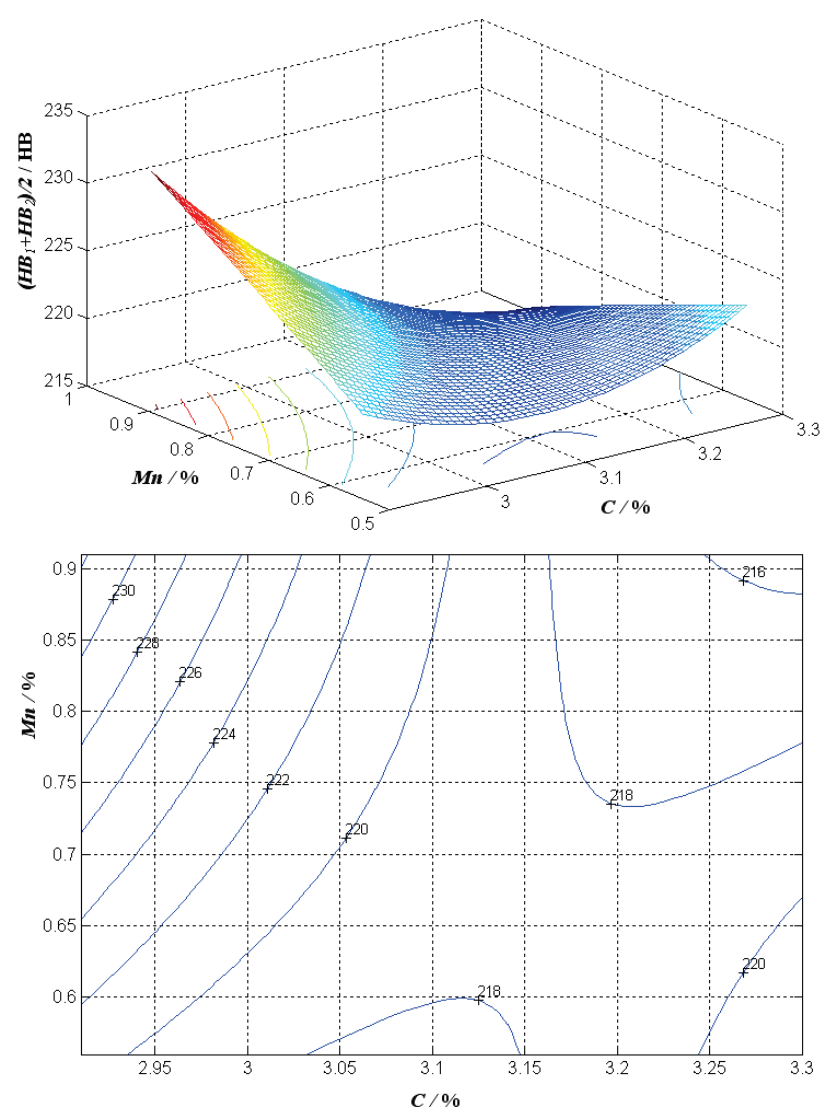

Figure $5\left(H B_{1}+H B_{2}\right) / 2=f(\mathrm{C}, \mathrm{Mn})-$ correlation $2^{\text {nd }}$ degree

Correlation equations for hardness variation depending on the content of manganese and silicon are:

$$
\begin{aligned}
& H B_{1}=-163,88 \cdot \mathrm{Mn}^{2}+13,36 \cdot \mathrm{Si}^{2}+6,24 \cdot \mathrm{Mn} \cdot \mathrm{Si}+ \\
& +239,53 \cdot \mathrm{Mn}-47,91 \cdot \mathrm{Si}+169,82
\end{aligned}
$$

Correlation coefficient: $R^{2}=0,42$. Inflection point: $\mathrm{Mn}=$ $0,76 \% ; \mathrm{Si}=1,61 \%, H B_{1}=222,36 \mathrm{HB}$.

$$
\begin{aligned}
& H B_{2}=-52,49 \cdot \mathrm{Mn}^{2}-8,69 \cdot \mathrm{Si}^{2}+161 \cdot \mathrm{Mn} \cdot \mathrm{Si}- \\
& -177,62 \cdot \mathrm{Mn}-82,8 \cdot \mathrm{Si}+348,66
\end{aligned}
$$

Correlation coefficient: $R^{2}=0,63$. Inflection point: $\mathrm{Mn}=$ $0,76 \%$; $\mathrm{Si}=1,61 \%, H B_{2}=222,36 \mathrm{HB}$. 

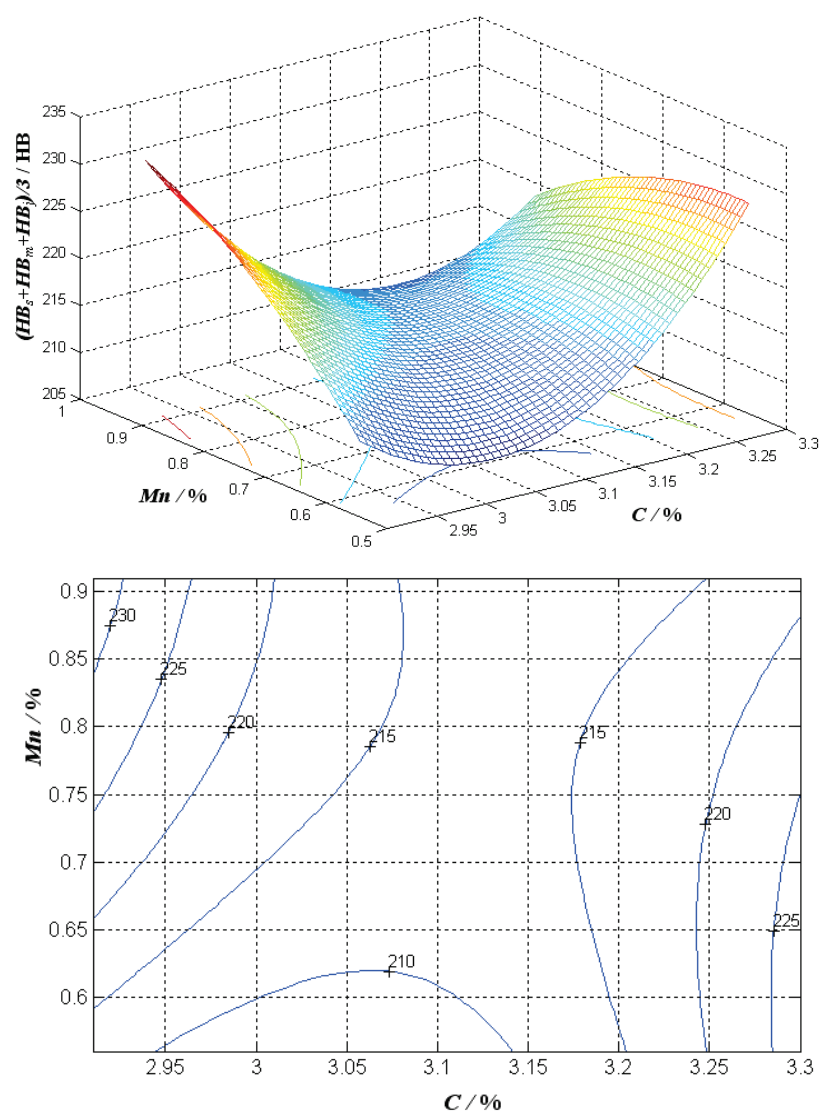

Figure $6\left(H B_{s}+H B_{m}+H B_{j}\right) / 3=f(\mathrm{C}, \mathrm{Mn})-$ correlation $2^{\text {nd }}$ degree

$$
H B_{s}=-85,68 \cdot \mathrm{Mn}^{2}-3,61 \cdot \mathrm{Si}^{2}+19,33 \cdot \mathrm{Mn} \cdot \mathrm{Si}+
$$$$
+97,81 \cdot \mathrm{Mn}+5,65 \cdot \mathrm{Si}+174,09
$$

Correlation coefficient: $R^{2}=0,37$. Point of maximum Stationary points: $\mathrm{Mn}=0,94 \% ; \mathrm{Si}=3,31 \%, H B_{s}=$ 229,66 HB.

$H B_{m}=-3,25 \cdot \mathrm{Mn}^{2}+28,06 \cdot \mathrm{Si}^{2}-72,02 \cdot \mathrm{Mn} \cdot \mathrm{Si}-$ $+155,94 \cdot \mathrm{Mn}-36,24 \cdot \mathrm{Si}+164,22$

Correlation coefficient: $R^{2}=0,63$. Inflection point: $\mathrm{Mn}=$ $1,10 \% ; \mathrm{Si}=2,06 \%, H B_{m}=213,07 \mathrm{HB}$.

$H B_{j}=-66,26 \cdot \mathrm{Mn}^{2}+23,16 \cdot \mathrm{Si}^{2}-65,87 \cdot \mathrm{Mn} \cdot \mathrm{Si}+$ $+241,97 \cdot \mathrm{Mn}-24,42 \cdot \mathrm{Si}+137,87$

Correlation coefficient: $R^{2}=0,68$. Inflection point: $\mathrm{Mn}=$ $0,91 \% ; \mathrm{Si}=1,83 \%, H B_{j}=226,38 \mathrm{HB}$.

$\frac{H B_{1}+H B_{2}}{2}=109,12 \cdot \mathrm{Mn}^{2}+102,02 \cdot \mathrm{Si}^{2}-$

$-90,83 \cdot \mathrm{Mn} \cdot \mathrm{Si}-10,03 \cdot \mathrm{Mn}-300,71 \cdot \mathrm{Si}+494,63$

Correlation coefficient: $R^{2}=0,61$. Point of minimum: Mn $=0,80 \% ; \mathrm{Si}=1,83 \%,\left(H B_{1}+H B_{2}\right) / 2=214,80 \mathrm{HB}$.

$\frac{H B_{s}+H B_{m}+H B_{j}}{3}=-177,73 \cdot \mathrm{Mn}^{2}+8,34 \cdot \mathrm{Si}^{2}+$
$+80,09 \cdot \mathrm{Mn} \cdot \mathrm{Si}+140,49 \cdot \mathrm{Mn}-93,43 \cdot \mathrm{Si}+245,58$
Correlation coefficient: $R^{2}=0,50$. Inflection point: $\mathrm{Mn}=$ $0,79 \% ; \mathrm{Si}=1,77 \%,\left(H B_{1}+H B_{2}\right) / 2=218,41 \mathrm{HB}$.
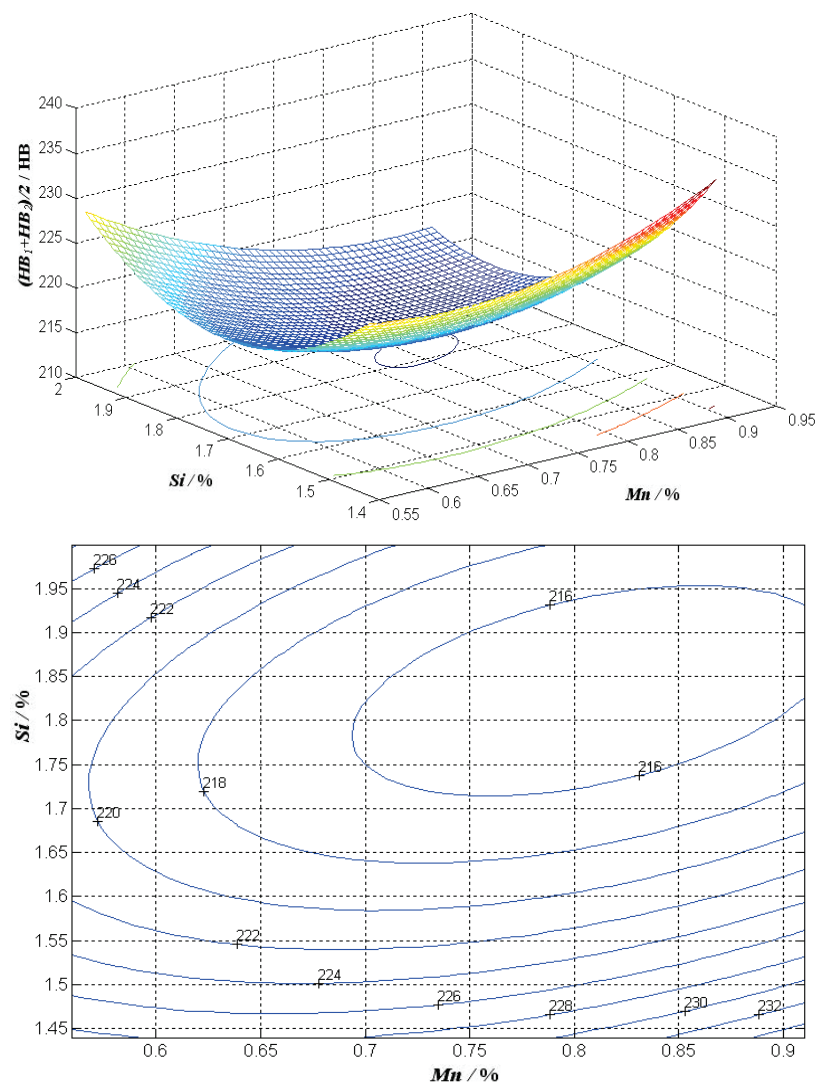

Figure $7\left(H B_{1}+H B_{2}\right) / 2=f(\mathrm{Mn}, \mathrm{Si})-$ correlation $2^{\text {nd }}$ degree
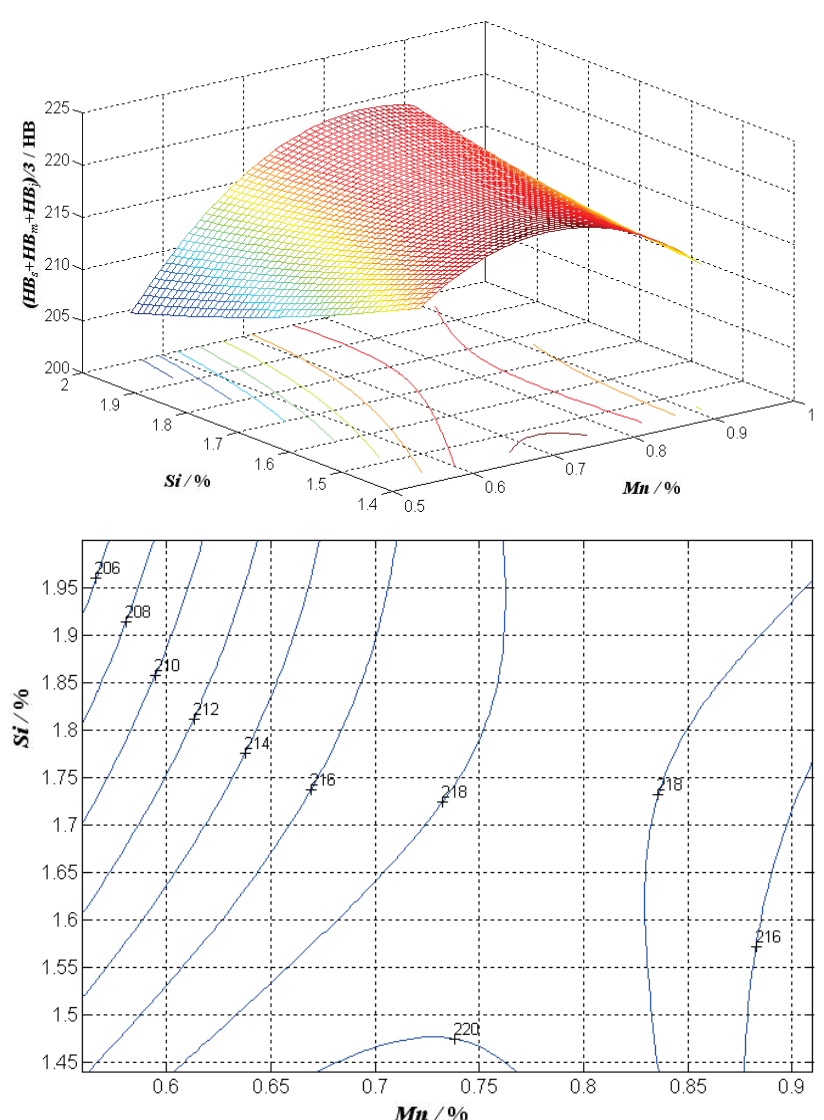

Figure $8\left(H B_{s}+H B_{m}+H B_{j}\right) / 3=f(\mathrm{Mn}, \mathrm{Si})-$ correlation $2^{\text {nd }}$ degree 
Taking into consideration the number of charges under analysis and the values of the $R^{2}$ coefficients, all the resulting correlations are representative. Out of the 21 correlations obtained, 6 show a minimum point, 1 a maximum point and the rest an inflexion point. The coordinates of the points mentioned above range within the technological limits except for the one given in Fig.4

The graphical representations allow the establishing of the values for the independent parameters (their domain of variation), so as to obtain a certain value for hardness.

Analysis of Fig. 3 shows that irrespective of the values of carbon and silicon content, within technological limits, the values of hardness will also range within the standard limits. For instance, if we want to obtain hardness values of $216 \div 220 \mathrm{HB}$, the independent parameters (the content of carbon and silicon) have to vary so as to have the resulting values for hardness within the hatched area.

On the cross section of the brake shoe the values of mean hardness are lower (Fig.4) although the hardness values $H B_{s}$ and $H B_{j}$ are close to $H B_{1}$ and $H B_{2}$ as a result of the lower values of $H B_{m}$, which can be explained by the solidification conditions that determine a larger quantity of graphite in the central part of the shoe. Irrespective of the content of carbon and silicon, within technological limits, the hardness values range within standard limits. It is to be mentioned that the inflexion point is not located within the technological domain.

Fig. 5 shows that all the values range within the product standards. As the content of manganese increases up to the carbon content corresponding to the inflexion point, hardness also grows, as a result of the formation of manganese carbide.

As to the correlation given in Fig. 6, hardness variation is similar to the one on the surface of the shoe, but one should notice that, like in the previous case, the hardness values are lower. The hardness values obtained in this case are very much alike, which means that manganese has a slighter influence upon the hardness of the shoe surface, as compared to its cross-section hardness

Irrespective of the values of manganese and silicon content, within technological limits, the values of hardness will range within the standard limits (Fig. 7 and 8). An increase of the silicon content as a result of its influence upon the formation of graphite leads to an increase of hardness both on the shoe surface and on its cross section. An increase of the content of manganese, as a result of its influence by carbide formation, leads to an increase of hardness.

\section{Conclusions}

The analysis of the research results leads to the following conclusions:

- the chemical composition of the cast iron used in making brake shoes grants the ranging of hardness within standard limits;

- the correlation relations clearly show the influence of carbon, manganese and silicon content upon hardness;
- there is a hardness difference between the cross section extremities and the centre of its cross section, which is explained by the solidification conditions;

- the level curves obtained in the graphical representation allow the choice of the independent parameters $(\mathrm{C}, \mathrm{Mn}, \mathrm{Si})$ so as to obtain the desired value for hardness;

- one can notice slight variations of hardness measured on the lateral surface and in the cross-section of the brake pad, respectively of their average, which is due to the narrow-limit variation of the chemical composition of the pads;

- in order to obtain a hardness ranging in the interval $197 \div 225 \mathrm{HB}$ (standard limits according to SR EN ISO 6506-1:2006), the chemical composition of the cast iron has to vary within narrow limits, namely $\mathrm{C} / \%=2,95 \div 3,2 \%, \mathrm{Mn} / \%=0,6 \div 0,7 \%, \mathrm{Si} / \%=$ $1,45 \div 1,95 \%$ maintaining $\mathrm{S} / \%=0,06 \div 0,09 \%$ and $\mathrm{P} / \%=0,85 \div 1,0 \%$;

- the values for the elements in the chemical composition (C, Mn, Si) can be most easily established graphically, using any of the graphical representations, but they can also be given analytically;

- the resulting correlations are useful both for research purposes and for elaboration practice of the cast iron used in making brake shoes for the drive or driven rolling stock.

\section{Acknowledgment}

This work was partially supported by the strategic grant POSDRU/159/1.5/S/137070 (2014) of the Ministry of National Education, Romania, co-financed by the European Social Fund - Investing in People, within the Sectoral Operational Programme Human Resources Development $2007 \div 2013$

\section{References}

[1] Aloman, A. et al. Treaty of materials science and engineering, Fundamentals of materials science, AGIR, 2006.

[2] Weiss, E.; Fedorko, G.; Futas, P.; Pribulova, A.; Vasocva, I. Dependence of quality properties for grey iron on used raw materials. // Metalurgija. 48, 1(2009), pp. 43-45.

[3] Specificication, no. 1 /SFMR/SDT/2000, Brake shoes for tractors and trailers rolling, approved by Romanian Railway Authority.

[4] Bacinschi, Z. et al. Treaty of materials science and engineering, Theoretical and obtain engineering metallic materials, AGIR, 2007.

[5] Andronache, C.; Socalici, A.; Heput, T. The influence of micro-coolers on the physical-mechanical charactersictics of the steel used in making railway monoblock wheels. // Technical gazette, 20, 3(2013), pp. 419-423.

[6] Pascu, L.; Putan, A.; Socalici, A.; Heput, T. Researches on the quality of pig iron to be used in making rail shoes. // Metalurgia International. 18, 4(2013), pp. 193.

[7] Abbasi, H. R.; Bazdar, M.; Halvaee, A. Effect of phosphorus as an alloying element on microstructure and mechanical properties of pearlitic gray cast iron. // Materials Science and Engineering. 444, 1-2(2007), pp. 314-317. DOI: 10.1016/j.msea.2006.08.108 
[8] Barton, D. C. Modelling of materials for automotive braking. // Materials Technology. 49, 6(2004), pp. 379-385. DOI: 10.1179/174328004x11469

\section{Authors' addresses}

Socalici Ana, Associate Professor Ph.D. Eng.

Politehnica University of Timisoara,

Faculty Engineering of Hunedoara,

5 Revolutiei street, Hunedoara, 331128, Romania

Phone: +40254207530/+40254207576,

E-mail: virginia.socalici@fih.upt.ro

\section{Pascu Liviu, Ph.D. Student}

Politehnica University of Timisoara,

Faculty Engineering of Hunedoara,

5 Revolutiei street, Hunedoara, 331128, Romania

Phone: +40254207530/+40254207576

E-mail: pascu59@yahoo.com

Ardelean Erika, Associate Professor Ph.D. Eng. Politehnica University of Timisoara,

Faculty Engineering of Hunedoara,

5 Revolutiei street, Hunedoara, 331128, Romania

Phone: $+40254207530 /+40254207576$

E-mail: erika.ardelean@fih.upt.ro

Heput Teodor, Professor Ph.D. Eng.

Politehnica University of Timisoara,

Faculty Engineering of Hunedoara,

5 Revolutiei street, Hunedoara, 331128, Romania

Phone: $+40254207530 /+40254207576$

E-mail: heput@fih.upt.ro 